\title{
PERANCANGAN SISTEM PROTOTIPE PENDETEKSI BANJIR PERINGATAN DINI MENGGUNAKAN ARDUINO DAN PHP
}

\author{
Wahyu Indianto 1), Awang Harsa Kridalaksana ${ }^{2)}$, Yulianto ${ }^{3)}$ \\ ${ }^{1,2)}$ Program Studi Ilmu Komputer, Fakultas Ilmu komputer dan Teknologi Informasi, Universitas Mulawarman. \\ 3) Program Studi Manajemen Informatika, Politeknik Pertanian Negeri Samarinda, \\ E-Mail : : relsiktrol@gmail.com ${ }^{1)}$; awangkid@gmail.com ${ }^{2)}$; yulianto.tile@ yahoo.com ${ }^{3)}$
}

\begin{abstract}
ABSTRAK
Banjir merupakan bencana alam yang sering terjadi di beberapa daerah di Indonesia salah satunya adalah di Kalimantan Timur, terkadang banjir terjadi di waktu malam dan di saat penghuni sedang tidak ada di rumah yang dapat mengakibatkan kerugian materil. Penelitian ini bertujuan untuk menghasilkan sistem prototipe untuk mengetahui kemungkinan terjadi banjir sebelum memasuki rumah menggunakan peringatan berupa pesan sms. Sistem prototipe pendeteksi banjir peringatan dini menggunakan Arduino sebagai mikrokontroler yang mengendalikan sensor ultrasonik dan sensor pendeteksi air dalam mendeteksi banjir serta ketinggiannya. Sms akan di kirim oleh sistem yang PHP dan Sms Gateway (Gammu) tergantung dari kondisi sensor air dan ketinggian air, serta website yang menginformasikan ketinggian air dan keadaan sensor pendeteksi air. Hasil dari penelitian ini adalah telah dibangun sebuah sistem prototipe pendeteksi banjir peringatan dini menggunakan Arduino dan $P H P$ yang memudahkan pengguna untuk mengetahui keadaan luapan air di parit pengguna.
\end{abstract}

Kata Kunci : Arduino, Gammu, Deteksi Banjir.

\section{PENDAhuluan}

Banjir merupakan hal yang tidak asing lagi terjadi di Indonesia khususnya di kota Samarinda. Pusat Studi Pembangunan Kalimantan Timur (PSPKT) menyatakan sering terjadinya banjir di Kota Samarinda walau hanya dua hingga 3 jam diguyur hujan, disebabkan tiga faktor yakni sistem drainase, hutan kota dan pertambangan. Dengan pernyataan tersebut menunjukkan bahwa kota Samarinda mudah dan sering terjadi banjir.

Perkembangan teknologi yang semakin pesat membuat para pengembang IT untuk terus meningkatkan berbagai macam inovasi dalam berbagai aspek. Salah satunya mencari tekhnologi baru yang dapat membantu dalam hal bencana banjir. Teknologi yang semakin berkembang membuat orang mulai berpikir bagaimana cara untuk mengantisipasi keadaan banjir tersebut. Sensor ultrasonic dan water level merupakan salah satu alat pendukung dan digunakan untuk menjadi parameter peringatan dini sebelum terjadinya banjir.

Alat pendeteksi banjir sangatlah bermanfaat, dengan adanya alat tersebut masyarakat di dekat pusat banjir atau yang di tempat yang sering terkena banjir dapat lebih awal menegetahui terjadinya bencana banjir. Namun pembuatan alat-alat tersebut membutuhkan dana yang tidak sedikit, bahkan bisa menyita waktu serta pengujian yang lama dan tentu saja harganya sangat tinggi, serta tidak semua orang bisa memilikinya karena memerlukan keahlian khusus mengoperasikannya atau dikatakan cukup rumit. Oleh karena itu diperlukan alat pendeteksi banjir sederhana yang dapat dipakai oleh masyarakat secara mandiri dan dapat berfungsi secara efektif.
Dengan menggunakan alat bantu berupa alat pendeteksi banjir, yang berfungsi untuk mengantisipasi terjadinya banjir. Prototipe pendeteksi banjir sederhana ini dapat mendeteksi kemungkinan banjir dan memberitahukan ke pengguna berupa pesan. Pesan tersebut akan mengirimkan peringatan dan memberitahukan bahwa air yang ada di selokan rumah telah meluap dan berpotensi masuk ke dalam rumah yang dapat menimbulkan banjir. Sehingga dapat digunakan sebagai alternatif untuk pemberitahuan awal ke pemilik rumah sebelum terjadinya banjir.

Dengan adanya alat ini diharapkan dapat membantu si pemilik rumah untuk mengetahui sejak dini terjadinya banjir sehingga dapat menyelamatkan barang - barang berharga (barang yg rentan akan air) untuk ditempatkan atau disimpan di tempat yang lebih aman.

\section{TINJAUAN PUSTAKA}

\subsection{Arduino}

Arduino didefinisikan sebagai sebuah platform elektronik yang open source, berbasis pada software dan hardware yang fleksibel dan mudah digunakan, yang ditujukan untuk seniman, desainer, hobbies dan setiap orang yang tertarik dalam membuat objek atau lingkungan yang interaktif.

Arduino sebagai sebuah platform komputasi fisik (Physical Computing) yang open source pada board input ouput sederhana, yang dimaksud dengan platform komputasi fisik disini adalah sebuah sistem fisik hyang interaktif dengan penggunaan software dan hardware yang dapat mendeteksi dan merespons situasi dan kondisi.

Kelebihan arduino dari platform hardware mikrokontroler lain adalah [1]: 
a. IDE Arduino merupakan multiplatform, yang dapat dijalankan di berbagai sistem operasi, seperti Windows, Macintosh dan Linux.

b. IDE Arduino dibuat berdasarkan pada IDE Processing, yang sederhana sehingga mudah digunakan.

c. Pemrograman arduino menggunakan kabel yang terhubung dengan port USB, bukan port serial. Fitur ini berguna karena banyak komputer yang sekarang ini tidak memiliki port serial.

d. Arduino adalah hardware dan software open source pembaca bisa mendownload software dan gambar rangkaian arduino tanpa harus membayar ke pembuat arduino.

e. Biaya hardware cukup murah, sehingga tidak terlalu menakutkan untuk membuat kesalahan.

f. Proyek arduino ini dikembangkan dalam lingkungan pendidikan sehingga bagi pemula akan lebih cepat dan mudah mempelajarinya.

g. Memiliki begitu banyak pengguna dan komunitas di internet dapat membantu setiap kesulitan yang dihadapi.

\subsection{Arduino Uno}

Papan Arduino satu ini merupakan papan mikrokontroler yang berukuran kecil atau dapat diartikan juga dengan suatu rangkaian berukuran kecil yang didalamnya terdapat komputer berbentuk suatu chip. Pada hardware arduino terdiri dari 20 pin yang meliputi:

a. 14 pin IO Digital (pin 0-13)

Sejumlah pin digital dengan nomor 0-13 yang dapat dijadikan input atau output yang diatur dengan cara membuat program IDE.

b. 6 pin Input Analog (pin 0-5)

Sejumlah pin analog bernomor 0-5 yang dapat digunakan untuk membaca nilai input yang memiliki nilai analog dan mengubahnya ke dalam angka antara 0 dan 1023.

c. 6 pin Output Analog (pin 3, 5, 6, 9, 10 dan 11) Sejumlah pin yang sebenarnya merupakan pin digital tetapi sejumlah pin tersebut dapat diprogram kembali menjadi pin output analog dengan cara membuat programnya pada IDE.

Papan Arduino Uno dapat mengambil daya dari USB port pada komputer dengan menggunakan USB charger atau dapat pula mengambil daya dengan menggunakan suatu AC adapter dengan tegangan 9 volt. Jika tidak terdapat power supply yang melalui AC adapter, maka papan Arduino akan mengambil daya dari USB port. Tetapi apabila diberikan daya melalui AC adapter secara bersamaan dengan USB port maka papan Arduino akan mengambil daya melalui AC adapter secara otomatis [1].

\subsection{Ethernet Shield}

Arduino Ethernet Shield adalah modul yang berfungsi menghubungkan Arduino board dengan jaringan internet, karna itu berdasar pada Wiznet W5100 ethernet chip. Pada papan Ethernet Shield terdapat slot mikro SD yang berbungsi sebagai tempat penyimpanan file sedangkan untuk mengakses mikro SD card mengunakan library SD yang terdapat di website Arduino. Untuk jenis arduino board yang bisa di pasangkan dengan ethernet shield W5100 yaitu Arduino Uno dan Mega [2].

\subsection{Ultrasonic Sensor}

Sensor ultrasonic merupakan sensor yang bekerja dengan cara memancarkan suatu gelombang dan kemudian menghitung waktu pantulan gelombang tersebut, sensor yang di gunakan adalah sensor HC-SR04 yang dapat mengukur jarak benda dari $2 \mathrm{~cm}-4 \mathrm{~m}$ dengan akurasi $3 \mathrm{~mm}$. Alat ini memiliki 4 pin, pin Vcc, Gnd, Trigger, dan Echo. Pin Vcc untuk listrik positif dan Gnd untuk groundnya. Pin Trigger untuk trigger keluarnya sinyal dari sensor dan pin Echo untuk penerima sinyal pantul dari benda [2].

\subsection{Water Sensor}

Water sensor merupakan sensor yang bekerja jika tersentuh oleh air yang saling menghubungkan 2 atau lebih lempengan kawat yang ada pada papan sensor.

\subsection{Gammu}

Gammu adalah semacam service yang disediakan untuk membangun aplikasi yang berbasis SMS Gateway. Setelah kita sukses membangun Gammu, maka kita bisa membangun aplikasi SMS Gateway dengan bahasa program atau platform apapun, baik itu web based dengan PHP maupun ASP atau apapun, dan juga desktop dengan menggunakan Delphi, VB atau lainnya [3]. Kelebihan dari Gammu ini adalah merupakan software opensource yang tersedia dalam bentuk source code atau binary nya, jadi tidak perlu khawatir tentang lisensinya. Selain itu Gammu juga tersedia untuk OS Windows maupun Linux.

\section{METODE PENELITIAN}

Metode pengembangan sistem kontrol adalah cara yang dilakukan untuk merancang hingga mengevaluasi sistem yang telah dirancang. Metode pengembangan yang digunakan adalah metode prototype. Metode ini dimulai dengan merancang sistem berdasarkan kebutuhan user, setelah itu dilakukan proses penulisan dan penanaman sistem pada mikrokontroler. Tahap implementasi digabung bersama dengan tahap evaluasi, karena saat ada kesalahan pada sistem maka perbaikan dilakukan saat itu juga.

1. Perancangan Sistem Kontrol

Tahap ini menghasilkan desain perangkat keras yang akan digunakan. Pengembangan yang awalnya berdiri sendiri mulai digabungkan dengan bahan elektronika lain hingga membentuk suatu rangkaian 
elektronik atau perangkat keras yang bisa digunakan dalam penelitian.

2. Penulisan dan Embed System

Setelah desain alat telah selesai maka dibuat program atau source code untuk mikrokontroler sebagai pengontrol alat elektronika lainnya. Pada tahap ini dituliskan program untuk mikrokontroler dan modem dengan platform Arduino menggunakan Software Arduino IDE beserta PHP dan menanamkan perintah pada mikrokontroler untuk memanipulasi rangkaian elektronika menjadi sistem terpadu.

3. Tahapan Penerapan (Implementasi)

Tahap ini merupakan kegiatan untuk mengimplementasikan program pada perangkat keras yang telah dirancang. Pada tahap ini dilakukan evaluasi kesesuaian program dengan Perangkat keras yang telah dirancang, mengkalibrasi berapa jarak antara sensor ultrasonic dengan dasar parit yang di inginkan, serta melakukan pengujian alat dengan simulasi air seperti pada parit dengan menyentuhkan sensor ke air. Tahap implementasi juga ditambahkan revisi source code system menyesuaikan kebutuhan sistem.

\section{HASIL DAN PEMBAHASAN}

\subsection{Pembuatan Rangkaian \& Desain Alat Peraga}

Rangkaian sistem ini terdiri dari Arduino uno r3, ultrasonic sensor, water level sensor dan breadboard dimana di hubungkan seperti pada gambar 1

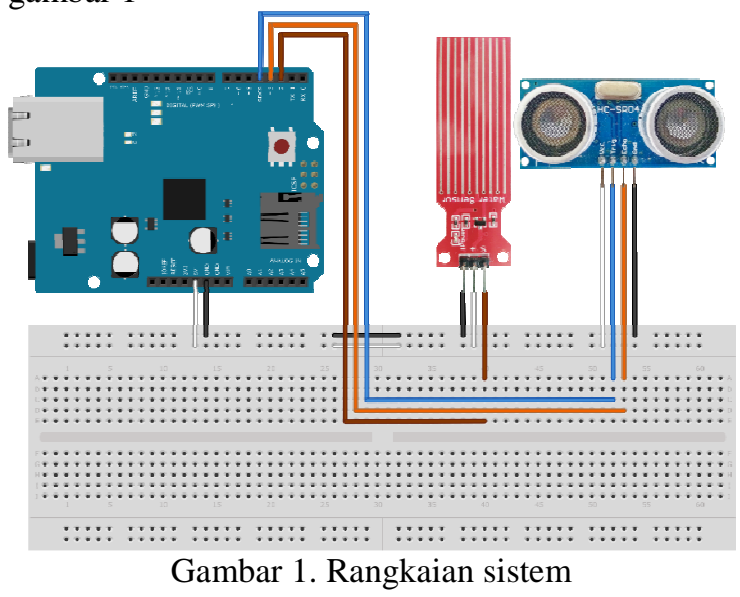

Peragaan alat akan menggunakan pipa sebagai bahan utamanya dan sensor ultrasonik di tempatkan tepat di atas pipa dan ember berisi air di tepatkan di bawah seperti pada gambar 2

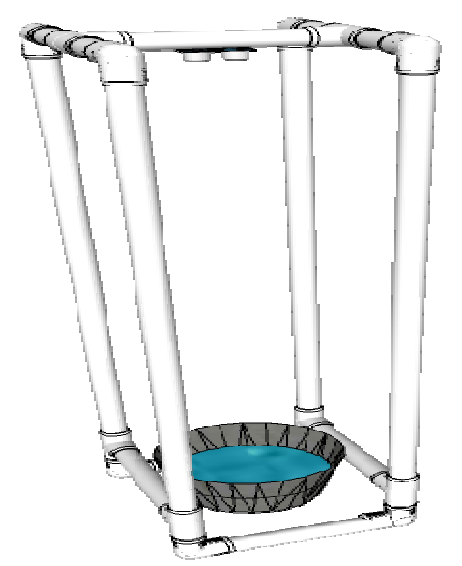

Gambar 2. Desain alat peraga

\subsection{Flowchart}

Flowchart ini merupakan awalan dan hingga akhir fungsi utama sistem yg di kerjakan secara berulang hingga sistem di hentikan, agar lbih jelas dapat dilihat pada gambar 3 .

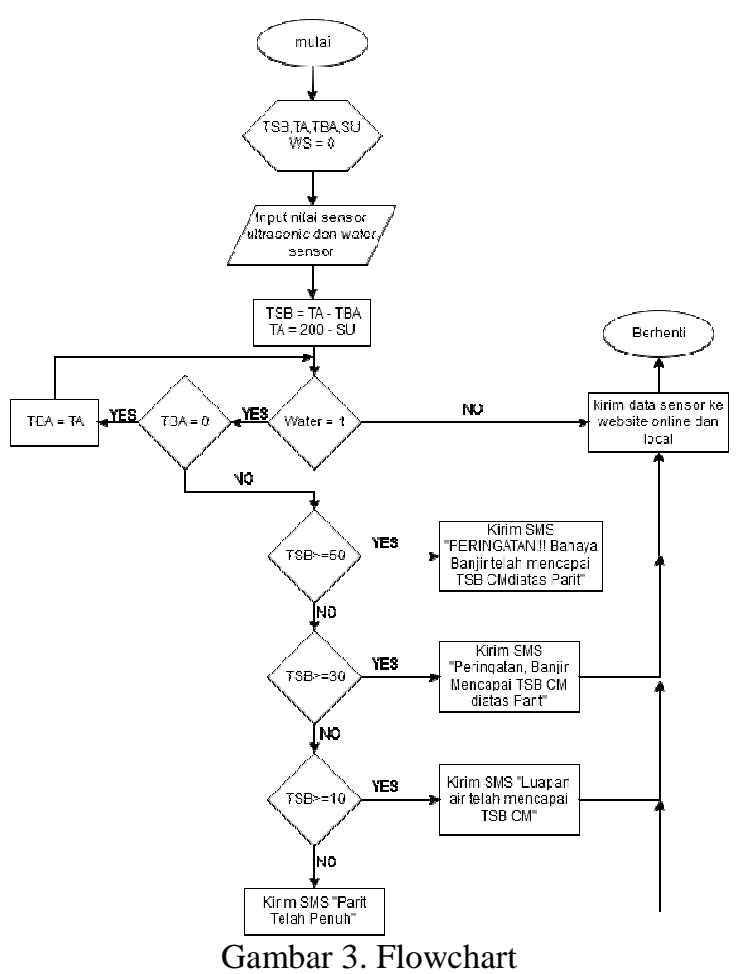

Flowchart diawali dengan penyiapan variabel yaitu TSB (Tinggi Setelah Batas), TBA (Tinggi Batas Air), TA (Tinggi Air), WS (Water Sensor), SU (Sensor Ultrasonik).Program akan mengolah data dari inputan sensor, sensor ultrasonik akan terus menghitung jarak ke air dan sensor air akan aktif jika terkena air. Sensor air tidak aktif maka water $=0$ dan jika aktif maka water $=1$.

Setelah sensor air aktif lalu menanyakan kondisi TBA apakah 0 atau tidak, jika iya maka akan menyimpan TA kedalam TBA lalu kembali ke posisi apakah sensor air aktif atau tidak. Jika sensor air aktif dan TBA tidak sama dengan 0 maka akan ke proses kondisi TSB apakah melebihi 50, 30, 10 
atau tidak sama 10 jika iya maka akan memulai proses pengiriman sms berdasarkan posisi TSB, setelah itu mengirim data ke website informasi lalu selesai.

\subsection{Pengujian Sistem}

Pada tahap ini semua komponen telah terhubung dengan baik dan telah memiliki program di dalam mikrokontroller juga telah menjalankan service gammu ditambah menghubungkan arduino dan modem ke laptop. Pengujian ini menggunakan peraga simulasi dengan mengunakan air di dalam ember untuk mengaktifkan water level sensor dan ultrasonik mendeteksi jarak, seperti pada gambar 4

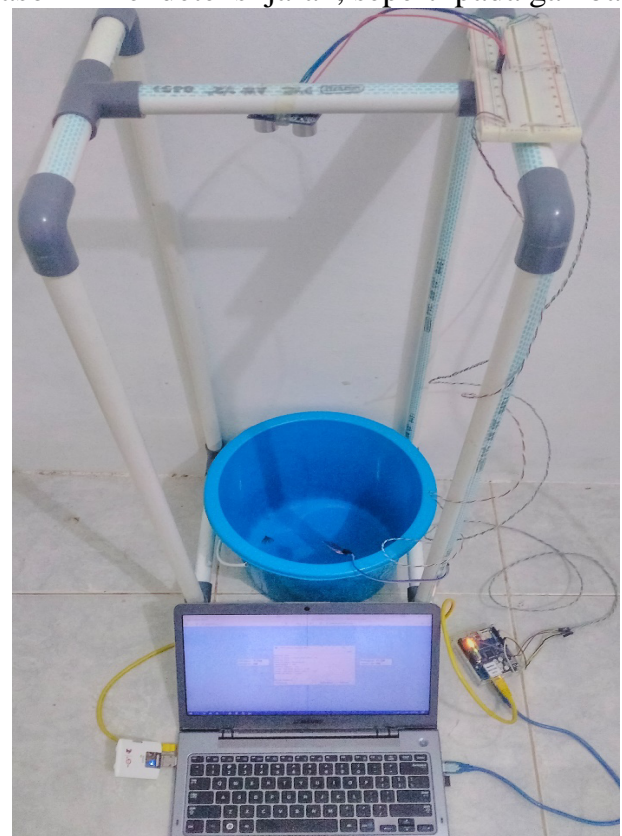

Gambar 4. Pengujian Sistem

Saat mikrokontroller bekerja dan sensor aktif, pada laptop akan menampilkan website lokal yang berada di browser kiri dan website hosting yang berada di browser kanan, beserta serial monitor arduino untuk memantau kondisi, seperti pada gambar 5

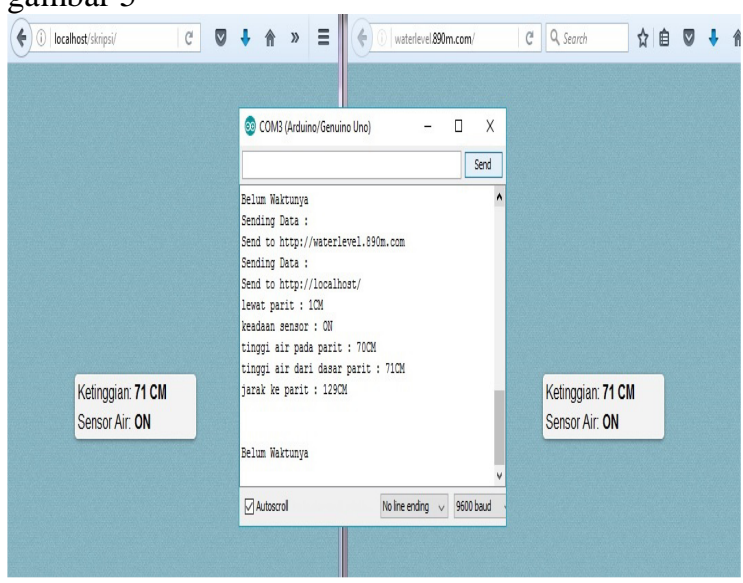

Gambar 5. Monitoring Sistem

Sistem akan mengirimkan sms dengan kondisi seperti pada tabel 1. Hasil Pengiriman SMS

Tabel 1. Hasil Pengiriman SMS

\begin{tabular}{|c|c|c|}
\hline $\begin{array}{c}\text { Water Level } \\
\text { Sensor }\end{array}$ & $\begin{array}{c}\text { Tinggi Air } \\
\text { dari Batas } \\
\text { Parit }\end{array}$ & SMS \\
\hline $\mathrm{ON}$ & $\begin{array}{c}\mathrm{TA}-\mathrm{BP}> \\
\mathrm{BP} \text { dan TA - } \\
\mathrm{BP}<10\end{array}$ & Parit telah Penuh \\
\hline $\mathrm{ON}$ & $\begin{array}{c}\mathrm{TA}-\mathrm{BP}> \\
\mathrm{BP} \text { dan TA - } \\
\mathrm{BP}<30\end{array}$ & $\begin{array}{l}\text { Luapan air telah } \\
\text { mencapai TA CM }\end{array}$ \\
\hline $\mathrm{ON}$ & $\begin{array}{c}\mathrm{TA}-\mathrm{BP}> \\
\mathrm{BP} \text { dan TA - } \\
\mathrm{BP}<50\end{array}$ & $\begin{array}{c}\text { Peringatan Banjir } \\
\text { Mencapai TA CM } \\
\text { diatas parit }\end{array}$ \\
\hline $\mathrm{ON}$ & $\mathrm{TA}-\mathrm{BP}>50$ & $\begin{array}{c}\text { PERINGATAN!!! } \\
\text { Bahaya Banjir } \\
\text { terlah mencapai } \\
\text { TA CM diatas } \\
\text { PArit }\end{array}$ \\
\hline Keterangan & $\begin{array}{l}\text { TA }=\text { Tingg } \\
\mathrm{BP}=\text { Batas } \\
\mathrm{CM}=\text { Centi }\end{array}$ & $\begin{array}{l}\text { ir } \\
\text { rit } \\
\text { ter }\end{array}$ \\
\hline
\end{tabular}

Saat kondisi pengiriman sms terpenuhi maka sistem akan mengirimkan sms ke no yg di daftarkan, seperti pada gambar 5

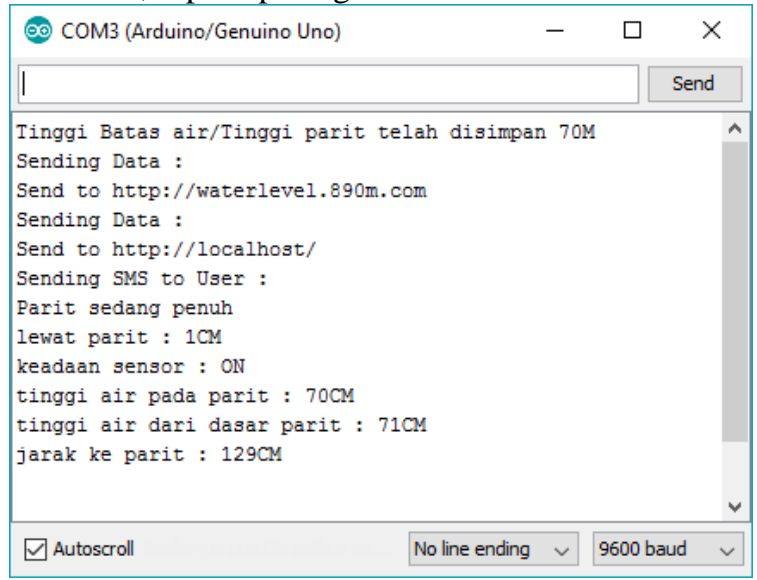

Gambar 5. Sistem Mengirimkan SMS

Pengguna akan menerima sms peringatan banjir dari sistem seperti pada gambar 6 .

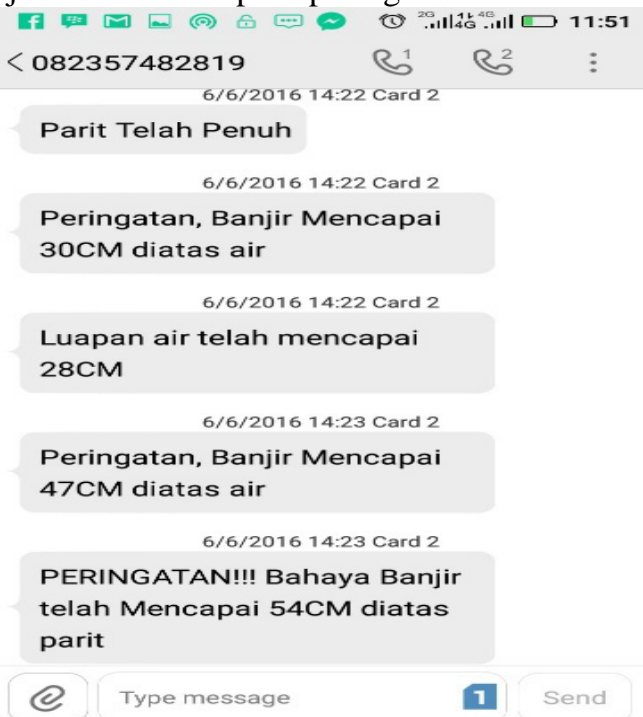

Gambar 6. SMS Berhasil Diterima Pengguna 


\section{KESIMPULAN}

Berdasarkan penelitian yang telah dilakukan oleh penulis, dapat diperoleh beberapa kesimpulan, diantaranya :

1. Telah dibangun sebuah sistem prototipe pendeteksi banjir peringatan dini menggunakan Arduino dan PHP.

2. Sistem memiliki fasilitas untuk memberikan peringatan kepada pengguna terhadap ancaman banjir menggunakan pesan sms.

3. Berfungsi sebagai sebuah website informasi mengenai keadaan parit pengguna.

\section{DAFTAR PUSTAKA}

[1]. Putra, Lucky Yuditia. 2013. Perancangan Sistem Pengukur Suhu Menggunakan Arduino dan C\#.Net. Skripsi. Teknik Elektro. Universitas Mercu Buana. Jakarta.

[2]. Santoso, Hari. 2015. Panduan Praktis Arduino untuk Pemula. Elangsakti.com. E-Book. Diakses pada 26 Juni 2015.

[3]. Widayanto , Ismail Fatagar. 2010. Membangun Sms Gateway Billing Rumah Sakit. Tugas Akhir. Ilmu Komputer. Universitas Sebelas Maret. Surakarta. 